\title{
Drivers of treeline shift in different European mountains
}

\author{
Pavel Cudlín ${ }^{1, *}$, Matija Klopčič ${ }^{2}$, Roberto Tognetti ${ }^{3,4}$, Frantisek Máliš̌ ${ }^{5,6}$, \\ Concepción L. Alados ${ }^{7}$, Peter Bebi ${ }^{8}$, Karsten Grunewald ${ }^{9}$, Miglena Zhiyanski ${ }^{10}$, \\ Vlatko Andonowski ${ }^{11}$, Nicola La Porta ${ }^{12}$, Svetla Bratanova-Doncheva ${ }^{13}$, \\ Eli Kachaunova ${ }^{13}$, Magda Edwards-Jonášová ${ }^{1}$, Josep Maria Ninot ${ }^{14}$, Andreas Rigling ${ }^{15}$, \\ Annika Hofgaard ${ }^{16}$, Tomáš Hlásny ${ }^{17}$, Petr Skalák ${ }^{1,18}$, Frans Emil Wielgolaski ${ }^{19}$ \\ ${ }^{1}$ Global Change Research Institute CAS, Academy of Sciences of the Czech Republic, České Budějovice 370 05, Czech Republic \\ ${ }^{2}$ University of Ljubljana, Biotechnical Faculty, Department of Forestry and Renewable Forest Resources, Slovenia \\ ${ }^{3}$ Dipartimento di Bioscienze e Territorio, Iniversità degli Studio del Molise, Contrada Fonte Lappone, 86090 Pesche, Italy \\ ${ }^{4}$ MOUNTFOR Project Centre, European Forest Institute, 38010 San Michele all Adige (Trento), Italy \\ ${ }^{5}$ Technical University Zvolen, Faculty of Forestry, 96053 Zvolen, Slovakia \\ ${ }^{6}$ National Forest Centre, Forest Research Institute Zvolen, 96092 Zvolen, Slovakia \\ ${ }^{7}$ Pyrenean Institute of Ecology (CSIC), Apdo. 13034, 50080 Zaragoza, Spain \\ ${ }^{8}$ WSL Institute for Snow and Avalanche Research SLF, 7260 Davos Dorf, Switzerland \\ ${ }^{9}$ Leibniz Institute of Ecological Urban and Regional Development, 01217 Dresden, Germany \\ ${ }^{10}$ Forest Research Institute, BAS 132, Kl. Ohridski Blvd. 1756 Sofia, Bulgaria \\ ${ }^{11}$ Faculty of Forestry, University Ss. Cyril and Methodius, Skopje, Macedonia \\ ${ }^{12}$ Research and Innovation Centre, Fondazione Edmund Mach (FEM) and MOUNTFOR Project Centre, \\ European Forest Institute, 38010 San Michele all Adige (Trento) Italy \\ ${ }^{13}$ Division of Ecosystem Research, IBER-Bulgarian Academy of Sciences, 1113 Sofia, Bulgaria \\ ${ }^{14}$ University of Barcelona, Department of Plant Biology, 08028 Barcelona, Spain \\ ${ }^{15}$ WSL Swiss Federal Institute for Forest, Snow and Landscape Research, Zürcherstrasse 111, 8903 Birmensdorf, Switzerland \\ ${ }^{16}$ Norwegian Institute of Nature Research, 7485 Trondheim, Norway \\ ${ }^{17}$ Faculty of Forestry and Wood Sciences, Czech University of Life Sciences, 165000 Prague, Czech Republic \\ ${ }^{18}$ Czech Hydrometeorological Institute, 14306 Prague, Czech Republic \\ ${ }^{19}$ University of Oslo, 0316 Oslo, Norway
}

\begin{abstract}
A growing body of evidence suggests that processes of upward treeline expansion and shifts in vegetation zones may occur in response to climate change. However, such shifts can be limited by a variety of non-climatic factors, such as nutrient availability, soil conditions, landscape fragmentation and some species-specific traits. Many changes in species distributions have been observed, although no evidence of complete community replacement has been registered yet. Climatic signals are often confounded with the effects of human activity, for example, forest encroachment at the treeline owing to the coupled effect of climate change and highland pasture abandonment. Data on the treeline ecotone, barriers to the expected treeline or dominant tree species shifts due to climate and land use change, and their possible impacts on biodiversity in 11 mountain areas of interest, from Italy to Norway and from Spain to Bulgaria, are reported. We investigated the role of environmental conditions on treeline ecotone features with a focus on treeline shift. The results showed that treeline altitude and the altitudinal width of the treeline ecotone, as well as the significance of climatic and soil parameters as barriers against tree species shift, significantly decreased with increasing latitude. However, the largest part of the commonly observed variability in mountain vegetation near the treeline in Europe seems to be caused by geomorphological, geological, pedological and microclimatic variability in combination with different land use history and present socio-economic relations.
\end{abstract}

KEY WORDS: Vegetation zone shift - Climate change $\cdot$ Climate models $\cdot$ Treeline ecotone European mountains $\cdot$ Ecosystem services

*Corresponding author: cudlin.p@czechglobe.cz
() The authors 2017. Open Access under Creative Commons by Attribution Licence. Use, distribution and reproduction are unrestricted. Authors and original publication must be credited. 


\section{INTRODUCTION}

Mountain regions are crucial areas for studying the impact of climate change on vegetation communities; steep climatic gradients enable testing of ecological, ecophysiological and evolutionary responses of flora to changing geophysical influences related to climate change. In addition, most of the species living there grow in conditions classified as their ecological limits (Körner 2012). Vegetation in European mountainous regions has been subjected to severe changes during the remote (e.g. Kullman 1988) and recent pasts (e.g. Vrška et al. 2009, Boncina 2011, Bodin et al. 2013, Elkin et al. 2013, Schwörer et al. 2014). Changes in species distribution and plant community composition have been the most often observed, although evidence of complete community exchange has not yet been registered.

A strong elevational zonation is typical of montane vegetation, caused mainly by steep climatic gradients. Vegetation zones are characterized by a specific structural-functional type of phytocoenosis constructed by particular main plant species (edificators) and roughly following latitude (latitudinal vegetation zones) or altitude (altitudinal vegetation zones or vegetation belts). Climatic zones along altitudinal gradients are compressed, with large habitat and species diversity in successive altitude vegetation zones. In these steep gradients, species richness decreases with increasing altitude, although topographic isolation results in increased levels of endemism (Pedrotti 2013).

The most obvious vegetation boundary at high elevations is that of the upper forest limit (Harsch \& Bader 2011). Owing to its diffuse character, it might be better to refer to the treeline ecotone, which consists of the belt between the boundary of the closed forest stand-timberline and the uppermost or northernmost scattered and stunted individuals of the forest-forming tree species regardless of their growth form and height (Holtmeier \& Broll 2005). Within this ecotone, the treeline (i.e. the line connecting the tallest patches of forest composed of trees of $\geq 3 \mathrm{~m}$ height) is often delimited; at this elevation, the mean temperatures for the growing season are ca. $6.4^{\circ} \mathrm{C}$ (Körner 2012). Climate is one of the most important limiting factors defining the spatial distribution of any species (Pearson \& Dawson 2003, Wieser et al. 2014). Temperature, especially summer mean temperature and temperature sums, is the primary factor causing the formation of treelines at the global scale (Grace et al. 2002, Moen et al. 2004), although it may be substantially affected by several other non-climatic factors, e.g. mass elevation effect (Ellenberg 1988), past land use or forest management (Gehrig-Fasel et al. 2007). The main factors affecting the expansion and/or retreat of tree stands at their upper limits are scale-dependent (Holtmeier 2009). At the global scale, treeline position is determined by growing-season temperatures (Körner \& Paulsen 2004), whereas at the landscape scale, second-order factors (i.e. climatic stress caused by wind or precipitation, natural disturbances and geomorphological factors), in addition to temperature, significantly affect treeline elevation and dynamics (Holtmeier \& Broll 2005, Hagedorn et al. 2014, Treml \& Chuman 2015). A recent review on the causes producing the upper limits of tree occurrence, introduced 6 current concepts: climatic stress (e.g. frost damage, winter desiccation), disturbances (e.g. wind, ice blasting, avalanches), insufficient carbon supply, limitation to cell growth and tissue formation, nutritional limitation and limited regeneration (Wieser \& Tausz 2007). Air temperature, as the strongest factor, influences the treeline in 2 different ways: temperatures during the warm part of the year are the main control of treeline elevation while temperatures during the cold part of the year can damage the living tissue of the trees (evergreen or deciduous species) (Jobbágy \& Jackson 2000). Climate change is likely to trigger latitudinal and elevational vegetation zone shifts, mainly by altering species mortality and recruitment, by exceeding physiological thresholds and changing natural disturbance regimes (Gonzalez et al. 2010).

Vegetation shifts need to be considered as an inherent adaptation mechanism allowing populations to track climatically suitable sites. Such shifts, however, can be limited by a variety of non-climatic factors, such as nutrient availability, soil conditions, landscape fragmentation or species-specific traits, including dispersal capacity, competition with ground vegetation, presence of mycorrhizal fungal symbionts or increasing virulence of pests and pathogens (Camarero et al. 2015b). In particular, species geographic ranges are expected to shift depending on their habitat preferences and their ability to adapt to new conditions. A growing body of evidence suggests that processes of treeline upward expansion, drought-induced retraction of species distributions and shifts of some dominant tree species may occur in response to global climate change (Kullman 1999, Kittel et al. 2000, Hansen et al. 2001, Payette et al. 2001, Theurillat \& Guisan 2001). Using a meta-analysis, treeline advance was recorded in $52 \%$ of 166 sites around the world (Harsch et al. 2009). On the other hand, there is 


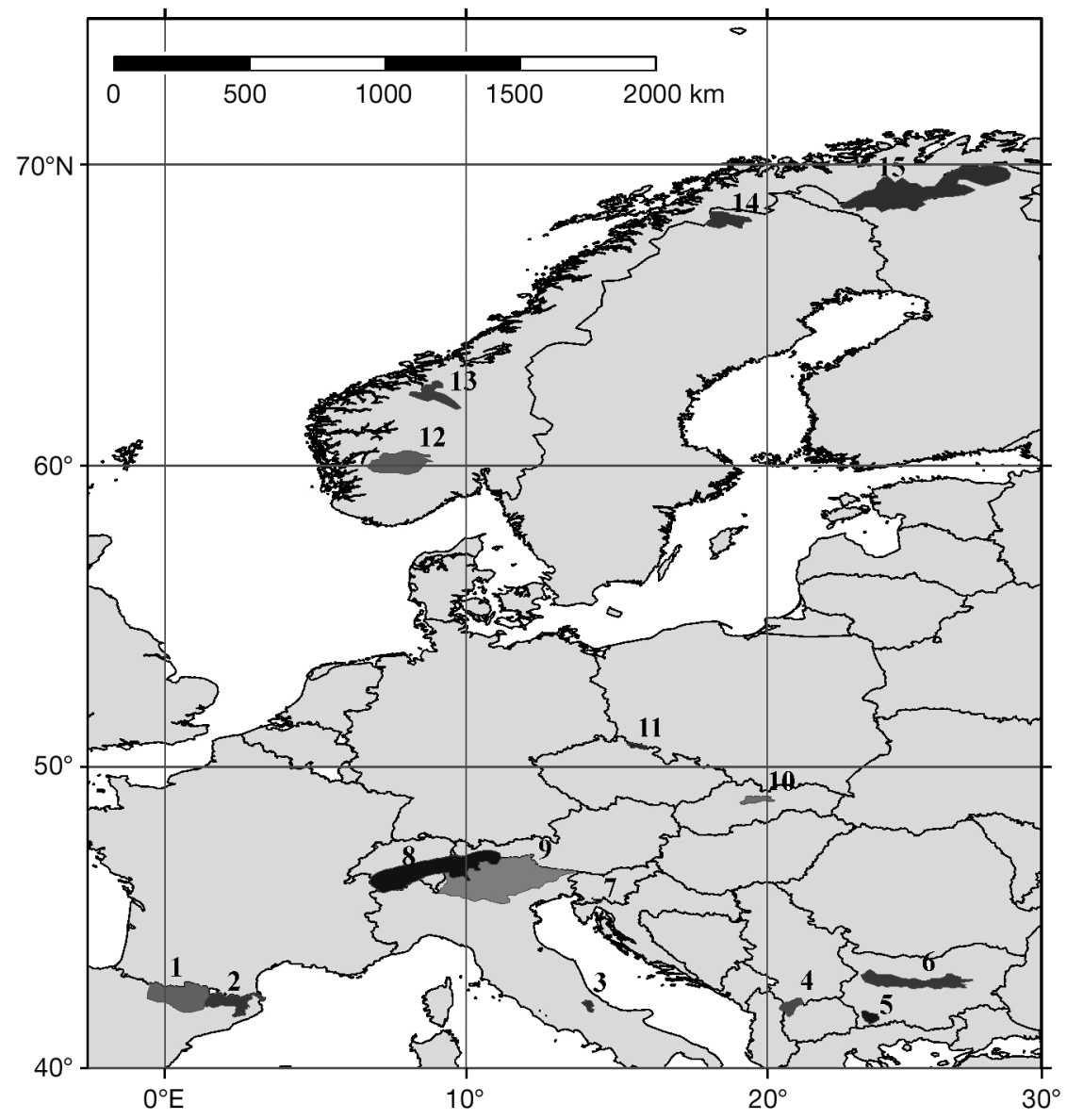

Fig. 1. Selected European mountains. Grey shading differentiates mountain areas. 1 Central Pyrenees (CP), 2 Eastern Pyrenees (EP), 3 Apennines (AP), 4 Shara Mts. (SH), 5 Pirin (PI), 6 Central Balkan Mts. (CB), 7 Northern Dinaric Mts. (DI), 8 Central Alps (CA), 9 Eastern Alps (EA), 10 Low Tatra Mts. (LT), 11 Giant Mts. (GM), 12 Hardangervidda (HG), 13 Dovre (DO), 14 Northern Swedish Lapland (NS), 15 Inner Finnmark/northernmost Finnish Lapland (FL)

evidence that treelines have always been dynamic and influenced by climate change and forest development cycles in the past (Kullman 1988, 2007, Gehrig-Fasel et al. 2007, Vladovi et al. 2014, Treml \& Chuman 2015).

There are 3 main aspects of environmental change to which trees are likely to respond: increasing temperature, rising concentrations of $\mathrm{CO}_{2}$ and increasing deposition of nitrogen (Grace et al. 2002, Lindner et al. 2014). The trees at the treeline accumulate carbohydrates, because autotrophic respiration is more limited by low temperature than photosynthesis. This means that factors such as temperature and nitrogen abundance, both of which affect the capacity of a tree to use the products of photosynthesis, will probably be more important than factors directly affecting photosynthesis, such as elevated $\mathrm{CO}_{2}$ (Fajardo et al. 2012).
However, climate signals can be confounded with the effects of human activity. Stronger treeline dynamics due to a coupled effect of climate change and highland pasture abandonment frequently occur in European mountain ranges (Ellenberg 1988). Other human-related influential factors, such as (overly) intensive forest management, pasture and grazing, may be regionally important as well. Direct humanrelated factors may be crucial in changing the species composition and structure of mountain forests, especially in treeline ecotones where climate change does not represent the key factor (Alados et al. 2014).

The aims of this study were to evaluate the effects of geographical position and different regional climatic and other site conditions on treeline ecotone characteristics of selected European mountain areas, to identify the natural and anthropogenic drivers of treeline shift. We further discuss the effects of climate and land use changes on biodiversity in forests below the treeline.

\section{METHODS}

To demonstrate and discuss the possibilities and limits of treeline species shift, including latitudinal and longitudinal heterogeneity, the current situation in 11 mountain areas from Italy to Norway and from Spain to Bulgaria were analysed (Fig. 1). To determine the influence of mountain massif size on the mesoclimatic and vegetation conditions, including treeline formation, we included large mountain complexes (Pyrenees, Alps, Scandes) as well as relatively small, separated mountains (Pirin and Giant Mountains) in this study. The characteristics of the treeline ecotone, including historical and recent human impacts on mountain ecosystems for the 11 mountain areas of interest, are summarized in Table 1. Extensive mountain massifs (Pyrenees, Alps, Scandes) were further divided into more homogeneous units (Central Pyrenees, Eastern Pyrenees, Central Alps, Eastern Alps, Hardangervidda, Dovre, Northern Swedish Lapland, Inner Finnmark/northernmost Finnish Lapland). To esti- 
Table 1. Timberline and treeline parameters and characteristics of human activities, changes according to climatic models and limits to climate change induced species shifts in selected European mountains. A1B, A2: emissions scenarios (IPPC); A.a.: Abies alba; A.p.: Acer pseudoplatanus; F.s.: Fagus sylvatica; L.d.: Larix decidua; P.a.: Picea abies; P.c.: Pinus cembra; P.h.: Pinus heldreichii; P.m.: Pinus mugo; P.p.: Pinus peuce; P.s.: Pinus sylvestris; P.u.: Pinus uncinata; T: timberline; Tr: treeline; TSL:

tree species limit; VZ: vegetation zone; C: century; mng: management. Elevation range of T and Tr: mean (min-max)

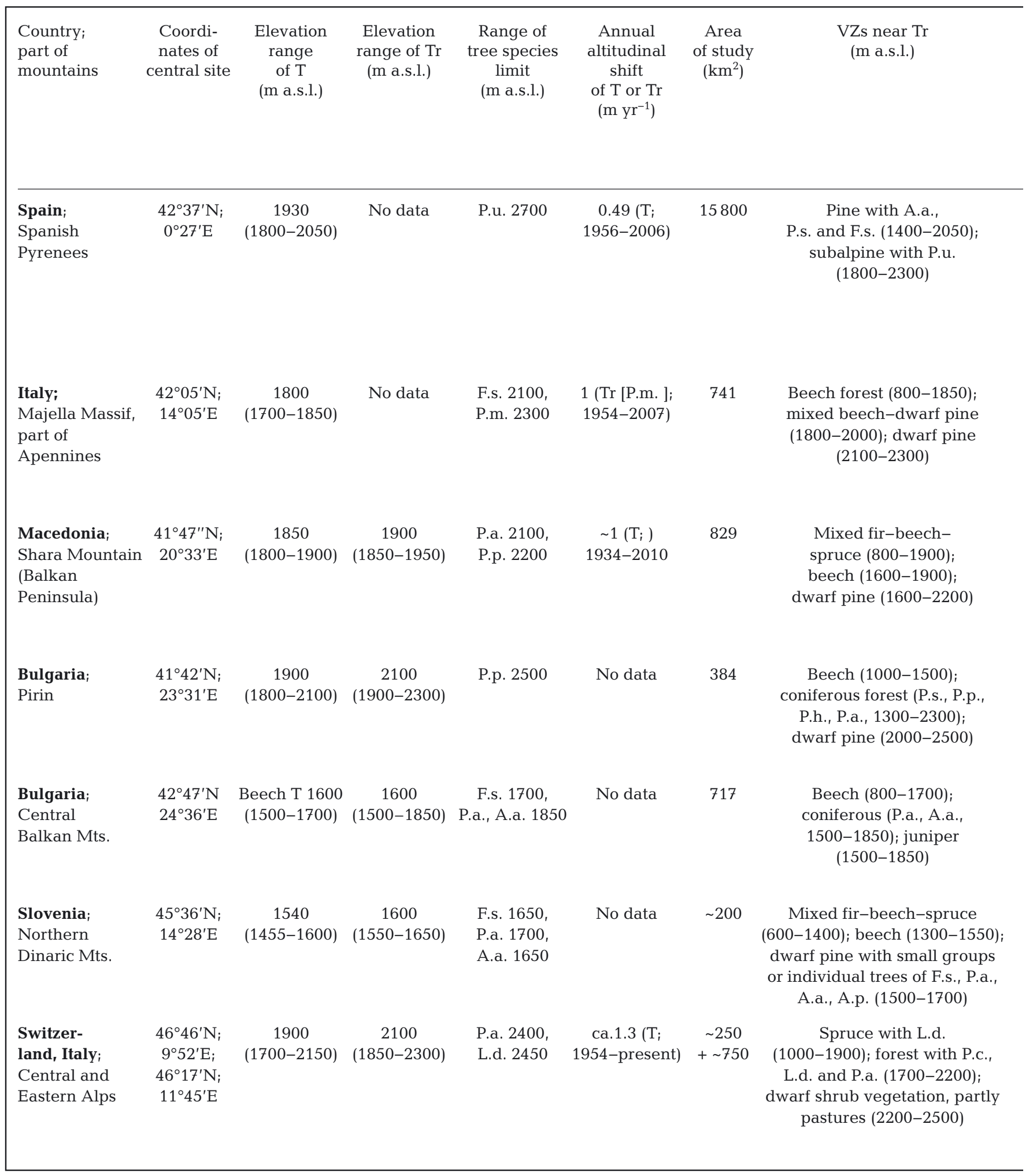




Human
influence
in VZs in past
and recently

$$
\begin{gathered}
\text { Annual } \\
\text { temperature }(T) \\
\text { and precipitation }(P) \\
\text { differences } \\
\text { between 1961-1990 } \\
\text { and 2021-2050; } \\
\text { mean of CORDEX } \\
\text { models }
\end{gathered}
$$

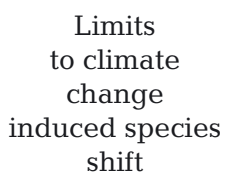

\author{
Since 11th C: \\ clear-cutting and grazing, \\ moderate on irregular \\ slopes and ridges; since 1930: \\ significant release of influence \\ but recovery mainly at \\ moderate elevations
}

Since 1000 BC: cutting, burning and grazing mng; since the mid-20th C: grazing intensity decreased; now occasionally managed and regeneration of P.m.

Since 14th C: clear-cutting and grazing to enlarge alpine pastures and to produce charcoal; since 1970: abandonment of traditional agricultural practices

Since 680 AD: intensive fires, deforestation and grazing; since 1962: traditional mng has changed; last decades tourism impact has increased

Human impact (mostly burning) started in 17 th $C_{i}$ excessive and improper forest mng; release of influence since 1980

15-18th C: slash, burn, grazing mng; 18-19th C: uncontrolled cutting; 20th C: irregular shelterwood systems and over-exploitation mng

Since 12th C: slash, burn, grazing mng; 13-19th C: intensive forest mng; at the end of the 19th C: decrease in grazing

\section{HIRHAM5 model: period $\Delta T 2021-2050$ \\ $=1.5-2^{\circ} \mathrm{C}_{i} \Delta T 2051-2080$ \\ $=4^{\circ} \mathrm{C} ; \Delta P 2021-2050$ \\ $=+5 \% ; \Delta P 2051-2080$ \\ $=+30 \%$ compared to 1960-1990}
HadCM3_A2, period 2020-2080:
$\Delta T_{\text {min_Jan } 2050}=1.7^{\circ} \mathrm{C} ;$
$\Delta T_{\text {min_Jan } 2080}=3.1^{\circ} \mathrm{C}$; $\Delta P 2050=-7 \%$; $\Delta P 2080=-23 \%$

Mean of 4 GCMs (CSIRO/Mk2, HadCM3, ECHAM4/OPYC3,

NCAR $-\mathrm{PCM}) ; \Delta T 2050=$

$2.6^{\circ} \mathrm{C} ; \Delta T 2100=5.3^{\circ} \mathrm{C}$;

$\Delta P 2050=-3 \% ; \Delta P 2100=-8 \%$

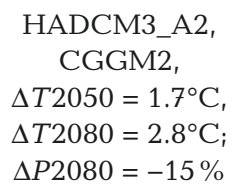

HADCM3_A2, CGCM2, $\Delta T 2050=1.7^{\circ} \mathrm{C}$, $\Delta T 2080=2.8^{\circ} \mathrm{C} ;$ $\triangle P 2050=-15 \%$; $\Delta P 2080=-15 \%$

DMI-HIRHAM5_A1B, period 2001-2100: $\Delta T 2050$ $=1.2^{\circ} \mathrm{C} ; \Delta T 2100=2.5^{\circ} \mathrm{C}$; $\Delta P 2050=+15 \mathrm{~mm}$; $\Delta P 2100=-18 \mathrm{~mm}$

ENSEMBLES models_ A1B, period 1980-2100:

$\Delta T 2050=1.2-1.8^{\circ} \mathrm{C} ;$

$\Delta T 2100=2.7-4.1^{\circ} \mathrm{C} ;$ $\triangle P 2050=0 \mathrm{~mm} ;$ $\Delta P 2100=-5 \mathrm{~mm}$
Inadequacy of substrata (rocky); climatic constraints (including growingseason extreme events, such as late-spring freezing, summer drought, etc.)

Low density of F.s. in $\mathrm{T}$, dispersal distances of F.s. seeds upslope; poor soils; excessive exposure to solar radiation in open areas

Differences in soil types between subalpine beech and mixed forest (poor calcareous soils or rankers on silicate bedrock); cliffs and rocks; cattle grazing

Rocky sites; extreme hydrothermal conditions; competition of shrubs and tree seedlings; locally intense pasturing

Low density of F.s.

in $T$, dispersal distances of F.s. seeds upslope; pasture intensity, new expansion of juniper stands

Impact of wild large ungulates on tree seedlings (especially A.a.); shallow, nutrient-poor soils (i.e. ranker and rendzina)

Frequent disturbances by snow avalanches and snow gliding; ongoing cattle grazing; game grazing in the coldest years
Em (1986), Strid et al. (2003), Bergant (2006) Amidžic et al. (2012)

Velchev (1997), Grunewald \& Scheithauer (2011), Raev et al. (2011)

Raev et al. (2011), Gikov et al. (2016), Zhiyanski et al. (2008, 2016)

Klopčič et al. (2010, 2015), Mina et al. (2017)

Tattoni et al. (2010), Kulakowski et al. (2011), Barbeito et al. (2012), Bebi et al. (2012), Dawes et al. (2015) 
Table 1 (continued)

\begin{tabular}{|c|c|c|c|c|c|c|c|}
\hline $\begin{array}{l}\text { Country; } \\
\text { part of } \\
\text { mountains }\end{array}$ & $\begin{array}{l}\text { Coordi- } \\
\text { nates of } \\
\text { central site }\end{array}$ & $\begin{array}{l}\text { Elevation } \\
\text { range } \\
\text { of } \mathrm{T} \\
\text { (m a.s.l.) }\end{array}$ & $\begin{array}{l}\text { Elevation } \\
\text { range of } \mathrm{Tr} \\
\text { (m a.s.l.) }\end{array}$ & $\begin{array}{l}\text { Range of } \\
\text { tree species } \\
\text { limit } \\
\text { (m a.s.l.) }\end{array}$ & $\begin{array}{l}\text { Annual } \\
\text { altitudinal } \\
\text { shift } \\
\text { of } \mathrm{T} \text { or } \mathrm{Tr} \\
\left(\mathrm{m} \mathrm{yr}^{-1}\right)\end{array}$ & $\begin{array}{l}\text { Area } \\
\text { of study } \\
\left(\mathrm{km}^{2}\right)\end{array}$ & $\begin{array}{l}\text { VZs near } \mathrm{Tr} \\
\text { (m a.s.l.) }\end{array}$ \\
\hline $\begin{array}{l}\text { Slovakia; } \\
\text { Dumbier Tatra } \\
\text { (part of Low } \\
\text { Tatra Mts) }\end{array}$ & $\begin{array}{l}48^{\circ} 55^{\prime} \mathrm{N} \\
19^{\circ} 31^{\prime} \mathrm{E}\end{array}$ & $\begin{array}{c}1400 \\
(1350-1450)\end{array}$ & $\begin{array}{c}1530 \\
(1400-1630)\end{array}$ & P.a. 1730 & $\begin{array}{c}\sim 0.3\left(\mathrm{Tr}_{i}\right. \\
1950-\text { present})\end{array}$ & $\sim 400$ & $\begin{array}{c}\text { Spruce-fir-beech } \\
(1200-1350) ; \text { spruce }(1300- \\
\text { 1550); P.m. with individual } \\
\text { P.a. trees (1400-1700) }\end{array}$ \\
\hline $\begin{array}{l}\text { Czech Republic; } \\
\text { Giant Mts }\end{array}$ & $\begin{array}{c}50^{\circ} 42^{\prime} \mathrm{N} \\
15^{\circ} 38^{\prime} \mathrm{E}\end{array}$ & $\begin{array}{c}1250 \\
(1130-1460)\end{array}$ & $\begin{array}{c}1320 \\
(1250-1460)\end{array}$ & P.a. 1500 & $\begin{array}{c}0.43\left(\mathrm{Tr}_{i}\right. \\
1936-2005)\end{array}$ & 550 & $\begin{array}{l}\text { Beech-spruce }(700-1050), \\
\text { P.a. dominates with increasing } \\
\text { altitude; spruce }(1000-1400) ; \\
\text { P.m. with P.a. trees }(1400-1560)\end{array}$ \\
\hline $\begin{array}{l}\text { Norway } \\
\text { Southern } \\
\text { Scandes }\end{array}$ & $\begin{array}{l}60^{\circ} 10^{\prime} \mathrm{N} ; \\
40^{\prime} \mathrm{E}_{i} 62^{\circ} 20^{\prime} \mathrm{N}_{i} \\
10^{\circ} 05^{\prime} \mathrm{E}\end{array}$ & 850 & 600-1050 & 1500 & $\begin{array}{c}0.8\left(\operatorname{Tr}_{i}\right. \\
1915-2007)\end{array}$ & 40600 & $\begin{array}{c}\text { Birch forest dominance } \\
\text { at high altitudes, but with } \\
\text { some scattered P.s. or P.a.; } \\
\text { mixed birch-conifer below } 800\end{array}$ \\
\hline $\begin{array}{l}\text { Norway, } \\
\text { Sweden, } \\
\text { Finland } \\
\text { Northern } \\
\text { Scandes }\end{array}$ & $\begin{array}{l}68^{\circ} 20^{\prime} \mathrm{N}_{i} \\
18^{\circ} 20^{\prime} \mathrm{E}_{i} \\
69^{\circ} 50^{\prime} \mathrm{N}_{i} \\
27^{\circ} 00^{\prime} \mathrm{E}\end{array}$ & $\begin{array}{l}\text { West: } 650 \\
\text { East: } 100\end{array}$ & $\begin{array}{l}\text { West: } 750 \\
\text { East: } 290\end{array}$ & $\begin{array}{l}\text { West: } 1000 \\
\text { East: } 0\end{array}$ & $\begin{array}{c}0.6(\mathrm{Tr} ; \\
1958-2008)\end{array}$ & 35000 & $\begin{array}{c}\text { Birch forest dominance } \\
\text { at all altitudes, but with some } \\
\text { scattered pines or pine stands } \\
\text { on sandy soils }\end{array}$ \\
\hline
\end{tabular}

mate the geographical position of these mountain units, 1 value was used for the geographical latitude and longitude of the locus of the studied mountain units. The analysed parameters of these 15 mountain units are shown in Table 2.

In addition, we calculated the following climate characteristics for all mountain units: annual mean air temperature, annual sum of precipitation, the growing season length and the date of the onset of the growing season. These characteristics were then compared for 2 distinct periods, 1961-1990 and 1991-2015 (Table 3). The climate characteristics were derived from the E-OBS gridded dataset of station observations version 13.1 (Haylock et al. 2008). We used the E-OBS version on the regular longitude-latitude grid with a horizontal resolution of 0.25 degrees. The climate data from all grid points within the mountain units or near their geographical borders were considered.

Data processing for 15 mountain units was made on the basis of data obtained from the literature and personal studies by the co-authors; these are summarized in Tables $1 \& 2$ and in Tables S1 \& S2 in the Supplement at www.int-res.com/articles/suppl/c073 p135_supp.pdf. In addition, a semi-quantitative valuation of abiotic, biotic and anthropogenic factors limiting an upward treeline shift was performed (Fig. 2). To answer the question how natural and anthropogenic factors have influenced treeline ecotone characteristics with a focus on treeline shift, redundancy analysis (RDA) was used to describe and test the effect of the explanatory variables (geographical position, size of the whole mountain massif, start of human influence and start of the decrease in human influence) on treeline ecotone characteristics (timberline elevation, width of the treeline ecotone, tree species forming the treeline and treeline shift per year) and identify groups of mountain units with similar variability of the dependent data (ter Braak \& Šmilauer 2012). The whole data set for this analysis is shown in Table S2. We tested both their simple effects, which show how much variation every explan- 


\begin{tabular}{|c|c|c|c|}
\hline $\begin{array}{c}\text { Human } \\
\text { influence } \\
\text { in VZs in past } \\
\text { and recently }\end{array}$ & $\begin{array}{c}\text { Annual } \\
\text { temperature }(T) \\
\text { and precipitation }(P) \\
\text { differences } \\
\text { between 1961-1990 } \\
\text { and 2021-2050; } \\
\text { mean of CORDEX } \\
\text { models }\end{array}$ & $\begin{array}{c}\text { Limits } \\
\text { to climate } \\
\text { change } \\
\text { induced species } \\
\text { shift }\end{array}$ & References \\
\hline
\end{tabular}

From 14th C to 1922:

mining, forest change

to spruce monocultures;

from 13th $\mathrm{C}$ to 1978: pastures

in upper parts of mountain

9-11th C: forest clear cutting, grazing in dwarf pine $\mathrm{VZ}$;

since 18th C: forest change

to spruce monocultures,

since 19th C: artificially planted

Grazed and browsed

by reindeer and livestock

(sheep and cattle)

over thousands of years

Grazed and browsed

by semi-domestic reindeer

for hundreds of years;

increased grazing from year 1960

\author{
Average of 10 RCM_B1: \\ $\Delta T 2050=1.8^{\circ} \mathrm{C} ;$ \\ $\triangle T 2100=3.7^{\circ} \mathrm{C} ;$ \\ $\triangle P 2050=+24 \mathrm{~mm} ;$ \\ $\Delta P 2100=-35 \mathrm{~mm}$
}

ALADIN_A1B, period 19612100: $\Delta T 2050=1.3^{\circ} \mathrm{C}$; $\Delta T 2100=3.4^{\circ} \mathrm{C} ;$ $\triangle P 2050=+25 \mathrm{~mm}_{;}$ $\Delta P 2100=-14 \mathrm{~mm}$

RegClim/MPI/Hadley: $\Delta T 2050=1.2^{\circ} \mathrm{C} ;$ $\Delta T 2100=2.2^{\circ} \mathrm{C} ;$ $\triangle P 2050=+23 \mathrm{~mm}$; $\Delta P 2100=-12 \mathrm{~mm}$

RegClim/MPI/Hadley: $\Delta T 2050=1.6^{\circ} \mathrm{C} ;$ $\Delta T 2100=2.9^{\circ} \mathrm{C} ;$ $\triangle P 2050=+18 \mathrm{~mm}$; $\Delta P 2100=-10 \mathrm{~mm}$

More rocky and nutrient- Körner (2003), poor soils; late frosts; Fridley et al. (2011), steep slopes with avalanches; Hlásny et al. $(2011,2016)$ absence of mature trees

Different soil types Treml and Banaš (2000), for F.s. and P.a. (cambisol Cudlín et al. (2013), versus podzol); only TSL of P.a. Treml \& Chuman (2015), could elevate on ranker Treml \& Migo (2015) soils in P.m. VZ

Sheep and reindeer grazing and episodic insect outbreaks (Epirrita)

Dalen \& Hofgaard (2005), Wielgolaski (2005),

Hofgaard et al. (2009), Kullman, Öberg (2009)

Continued grazing regime and frequent episodic insect outbreaks (Epirrita) Wielgolaski (2005),
Dalen \& Hofgaard (2005),

Tømmervik et al. (2005), Hofgaard et al. (2009), Aune et al. (2011), Mathisen et al. (2014) atory variable can explain separately, without using the other variables, and their conditional effects, which depend on the variables already selected in the model. The statistical significance of the explanatory variables was tested using a Monte Carlo permutation test, and only predictors with $\mathrm{p} \leq 0.05$ were included in the subsequent RDA (Šmilauer \& Lepš 2014).

To find the drivers of biodiversity loss in forests, meadows and animal communities (dependent variables), the explanatory variables (geographical position, timberline elevation, tree species forming the treeline, start of human influence, start of the decrease in human influence and temperature increase between the 2 periods 1961-1990 and 2021-2050) were tested again by RDA in Canoco 5 as mentioned above (Figs. $3 \& 4$ ). The whole data set for this analysis-including additional information about treelines in the mountain areas of interest, with a focus on treeline shift (its rate, drivers, limits and problems with its assessment) — is presented in Tables S1 \& S2.
Selected univariate graphs were constructed to visualize the data of relationships between the explanatory and dependent variables of all analyses, which were not seen distinctly from the results of the multivariate statistics or linear regression (Fig. 5).

\section{RESULTS}

\subsection{Effect of environmental variables on treeline ecotone characteristics with a focus on treeline shift}

The variation in the dependent variables (timberline elevation, width of treeline ecotone, tree species forming the treeline and treeline shift per year) was significantly affected only by latitude and size of the whole mountain massif (Fig. 3). The adjusted explained variability by all explanatory variables was $34.2 \%(F=4.6, \mathrm{p}=0.01)$. The RDA diagram shows that in the mountains located more to the north, the 


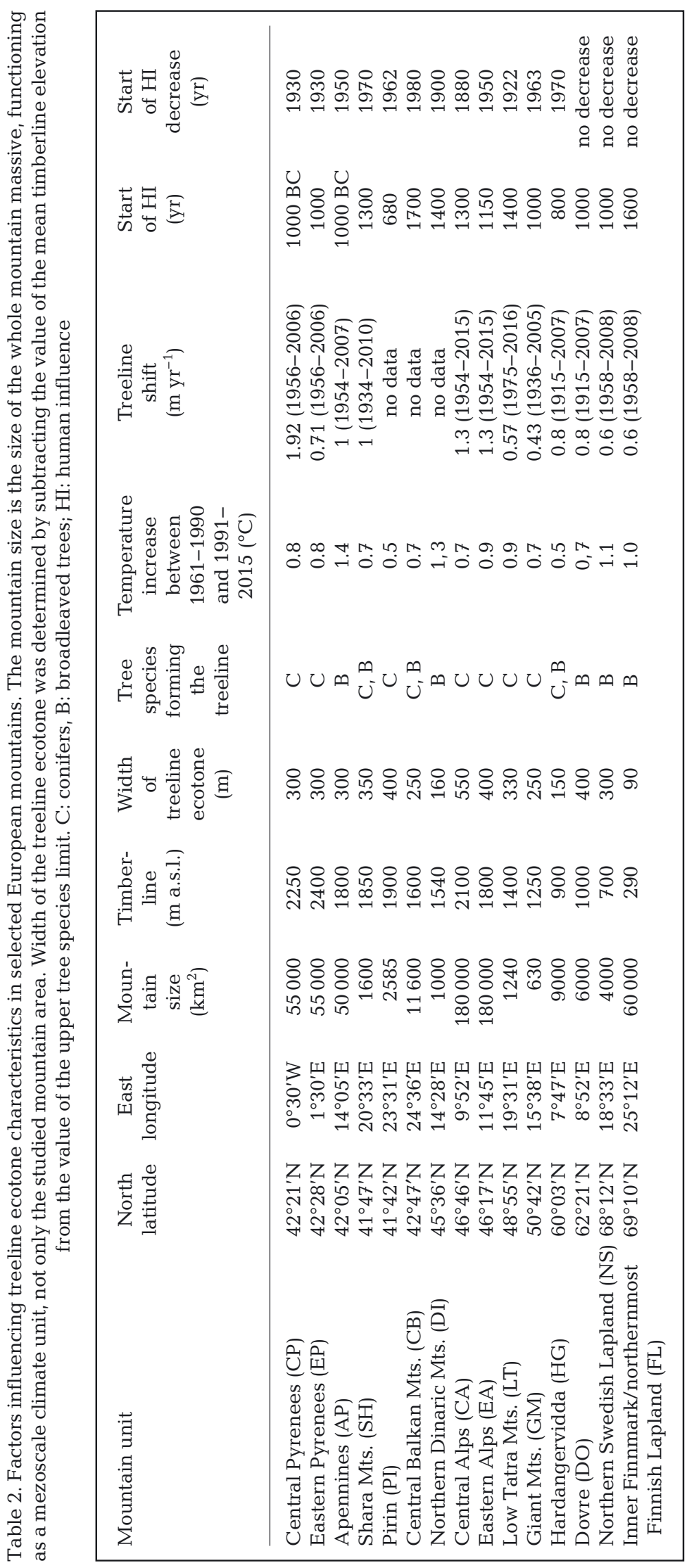

treeline ecotone is narrower, treeline shift is smaller, the timberline occurs at lower elevations, and the treeline is formed more by broadleaved species. Higher values of treeline ecotone width and treeline shift were found in the mountains with a greater size of the whole mountain massif.

When every explanatory variable was tested separately, values of the start of the decrease of human influence in the mountains also had a significant effect on the variation of the tree line ecotone data (explained variation $=20.6 \%$, pseudo $-F=$ $3.4, p=0.024)$. Some selected relationships of the explanatory and dependent variables, even those not showing significant effects on the variation in the tree line ecotone parameters, are depicted in Fig. 5.

\subsection{Effect of recent changes in climate and land use on the biodiversity}

Biodiversity loss in forests, meadows and animal communities, analysed by RDA, was explained by geographical position, treeline species composition and temperature increase between the 2 periods 1961-1990 and 2021-2050 (Fig. 4). The adjusted explained variation by all explanatory variables was $63.2 \%(F=5.8, \mathrm{p}=$ 0.001 ). The RDA results indicated that biodiversity loss in forest communities increased with increasing latitude and longitude as well as in the case where broadleaved species formed the treeline. In contrast, the highest biodiversity loss in meadows was found in the mountains positioned more to the south and with higher temperature increase. The biodiversity loss in animal communities was negatively correlated with longitude and temperature increase.

\section{DISCUSSION}

The comparison of several mountain areas situated across Europe shows a variation in understanding of what constitutes the treeline across countries. The primary issue is the different approach to the definition of forest when applying a tree height threshold. This threshold decreases from 
Table 3. Differences of selected climatic parameters between the 2 study periods (1961-1990 and 1991-2015) in selected European mountains

\begin{tabular}{|lcccc|}
\hline & $\begin{array}{c}\text { Length } \\
\text { of growing } \\
\text { period } \\
(\mathrm{d})^{\mathrm{a}}\end{array}$ & $\begin{array}{c}\text { Beginning } \\
\text { of growing } \\
\text { season } \\
(\mathrm{d})^{\mathrm{b}}\end{array}$ & $\begin{array}{c}\text { Mean } \\
\text { annual } \\
\text { temperature } \\
\left({ }^{\circ} \mathrm{C}\right)\end{array}$ & $\begin{array}{c}\text { Mean } \\
\text { annual } \\
\text { precipitation } \\
(\%)\end{array}$ \\
\hline Central Pyrenees & 13.5 & -8.9 & 0.8 & -10.7 \\
Eastern Pyrenees & 11.7 & -9.1 & 0.8 & -9.2 \\
Apennines & 28.4 & -23.2 & 1.4 & 5.7 \\
Shara Mts. & 1.6 & 0.1 & 0.7 & -10.0 \\
Pirin & 2.6 & -1.4 & 0.5 & 2.7 \\
Central Balkan Mts. & 16.9 & -13.6 & 0.7 & 7.6 \\
Northern Dinaric Mts. & 16.0 & -9.5 & 1.3 & -5.6 \\
Central Alps & 14.7 & -8.6 & 0.7 & 6.2 \\
Eastern Alps & 12.5 & -9.6 & 0.9 & -3.3 \\
Low Tatra Mts. & 2.4 & -3.4 & 0.9 & -9.1 \\
Giant Mts. & -1.0 & 1.3 & 0.7 & 5.5 \\
Hardangervidda Blefjell & 6.3 & 3.4 & 0.5 & 5.6 \\
Dovre & 13.8 & 3.2 & 0.7 & 6.4 \\
Northern Swedish Lapland & 8.1 & 0.5 & 1.1 & -2.7 \\
Inner Finnmark/northern- & 1.7 & 0.8 & 1.0 & 7.7 \\
most Finnish Lapland & & & & \\
aPositive numbers indicate a prolongation & & \\
bNegative numbers indicate an earlier beginning & & & \\
\hline
\end{tabular}

Central Pyrenees (CP)

Eastern Pyrenees (EP)

Apennines (AP)

Shara Mts. (SH)

Pirin (PI)

Central Balkan Mts. (CB)

Northern Dinaric Mts. (DI)

Central Alps (CA)

Eastern Alps (EA)

Low Tatra Mts. (LT)

Giant Mts. (GM)

Hardangervidda (HG)

Dovre (DO)

Northern Swedish Lapland (NS)

Inner Finnmark/northernmost Finnish Lapland (FL)

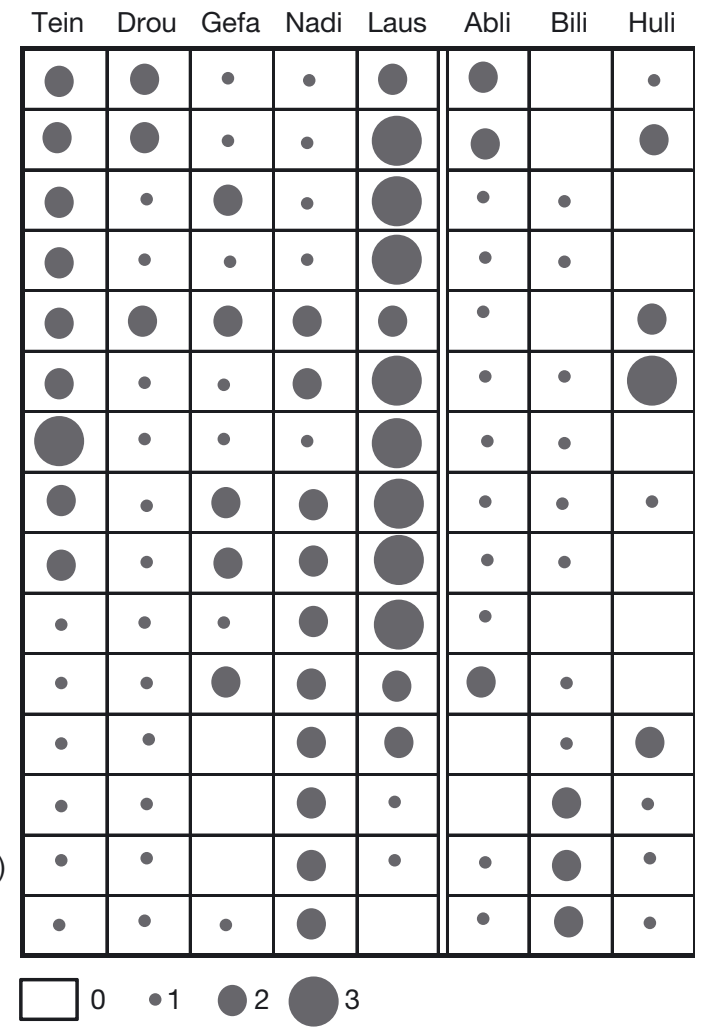

Fig. 2. Rates of treeline drivers (temperature increase [Tein], land use change [Laus]) and treeline shift limits (drought [Drou], geomorphological factors [Gefa], natural disturbances [Nadi], other abiotic, biotic and human factors) in selected European mountains. Abli, Bili and Huli: abiotic, biotic and human treeline shift limits, respectively). Rate of treeline driver influence-0: no influence; 1 : weak influence; 2 : middle influence; 3 : strong influence
5 m (Jeník \& Lokvenc 1962) to $3 \mathrm{~m}$ (Körner 2012) in Northern and Central Europe to only 2 m (Holtmeier 2009) in Central and Southern Europe, where even shrubby stands (e.g. Pinus mugo) are considered as a forest in some countries, e.g. in Spain, Italy and Macedonia (Batllori et al. 2009). Another problem is a different designation of forest stands below the treeline: 'upper montane forests' in Central Europe and 'subalpine forests' in Southern Europe (Ellenberg 1988). Further differences are related to the tradition of different branches of science (e.g. a more traditional 'geobotanical' approach in Central Europe versus a more experimental approach in Western Europe), especially in the rate of applying new progressive methods (e.g. climatic modelling or molecular biological methods).

Our comparison of selected regions (Tables 1 \& 2, Figs. 1 \& 2) showed that southern mountains, compared to those located more centrally and in the north had (1) a longer and more profound exploitation by humans in the past; (2) greater differences in climatic parameters (temperature, length of growing period) between the 2 periods 1961-1990 and 1991-2015 (Table 3) and (3) more dramatic climate change scenarios, especially concerning temperature increases. Longitude also had some influence on the start and intensity of human influence, and on treeline elevation and rate of treeline shift (Table 2, Fig. 5). The occurrence of broadleaf tree species in the treeline ecotone in the northern (and to some extent the southern) countries distinguishes these from the Central European countries, where conifers prevail. It is interesting that grazing, an important factor shaping treeline ecosystems (Dirnböck et al. 2003, 


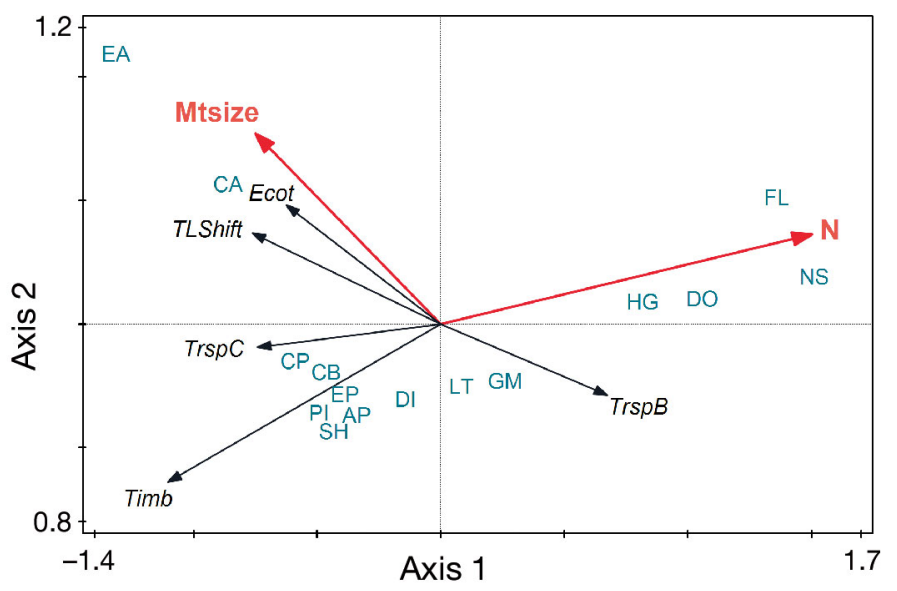

Fig. 3. Redundancy analysis diagram, with variation in timberline elevation, width of treeline ecotone, the tree species forming the treeline, and treeline shift used as dependent variables, explained by explanatory variables (latitude, mountain size). Mountain units (blue) are projected as the centres of abbreviations (see Table 2). Explanatory variables account for $43.6 \%$ of the total variation in the dependent data. The first canonical axis explained $46.6 \%$ of variation, the second axis explained $3.0 \%$ of variation. Dependent variables (black) are Ecot: altitudinal width of treeline ecotone, TLShift: treeline shift, $\operatorname{Trsp} C(\operatorname{TrspB})$ : treeline formed by conifers (broadleaved trees), Timb: timberline elevation. Explanatory variables (red) are N: north latitude, Mtsize: size of the mountain massif

Gehrig-Fasel et al. 2007), limits treeline shift in half of the countries of interest, regardless of latitude, longitude or recent political developments (Shara, Pirin, Central Balkans, Alps, Scandes; Fig. 2).

Despite the stated differences between studies looking at climate change impacts on the treeline, it is clear that current and future changes in temperature will seriously affect treeline ecotones in all mountain ranges of Europe. Winter is a period when treeline stands and individual trees have to survive severe, life-limiting conditions (Wieser \& Tausz 2007). Therefore, winter warming might increase the chance of young trees surviving and passing the most critical period from seedling to sapling and further to the mature stage (Körner 2003). There is already much evidence worldwide that winter warming is one of the significant drivers of treeline advance (Harsch et al. 2009). Although it is expected that tree growth at the upper distributional margins (and in the northern European countries) will increase due to ongoing climate change (Peñuelas \& Boada 2003, Chen et al. 2011, Hlásny et al. 2011, Lindner et al. 2014), extremes in temperature (e.g. black frosts, temperature reversals in the spring) or winter precipitation (e.g. lack of snow, drought) might also limit

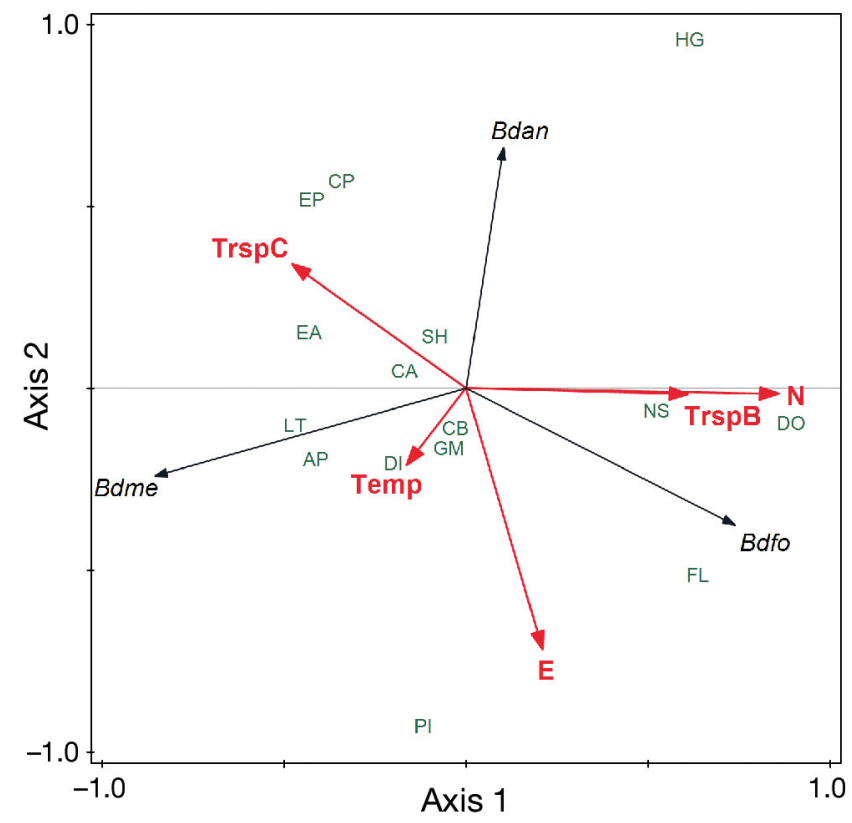

Fig. 4. Redundancy analysis diagram, with variation in biodiversity loss in forests, meadows and animal communities, used as dependent variables, explained by explanatory variables (geographical position, tree species forming the treeline and temperature increase between the 2 study periods [1961-1990 and 2021-2050]). Mountain units (green) are projected as centres of abbreviations (see Table 2). Explanatory variables account for $76.3 \%$ of total variation in the dependent data. The first canonical axis explained $48.4 \%$ of variation, the second axis explained $18.3 \%$ of variation. Dependent variables (black) are $B d f o / B d m e / B d a n$ : biodiversity loss in forests/meadows/animal communities. Explanatory variables (red) are N: north latitude, E: east longitude, TrspC (TrspB): treeline formed by conifers (broadleaved trees), Temp: temperature increase between the 2 study periods

this process in the future in some regions and local situations (Holtmeier \& Broll 2005, Hagedorn et al. 2014). An earlier start to the growing period (especially in the Apennines, Central Balkan and Spanish Pyrenees; see Table 2) can play a negative role in the resistance of trees and seedlings to early spring frosts. On the other hand, at lower distributional margins (and in Southern European countries), it is expected that tree growth will decrease or forests will experience some level of dieback due to drought (Breshears et al. 2005, Piovesan et al. 2008, Allen et al. 2010, Huber et al. 2013). A serious implication is the positive effect that warming can have on root rot fungi and populations of bark beetles resulting in large-scale disturbances to temperate and also highaltitude forests (Jankovský et al. 2004, Elkin et al. 2013, Millar \& Stephenson 2015).

Although recent upward advances of treeline ecotones are widespread in mountain regions (Harsch et 

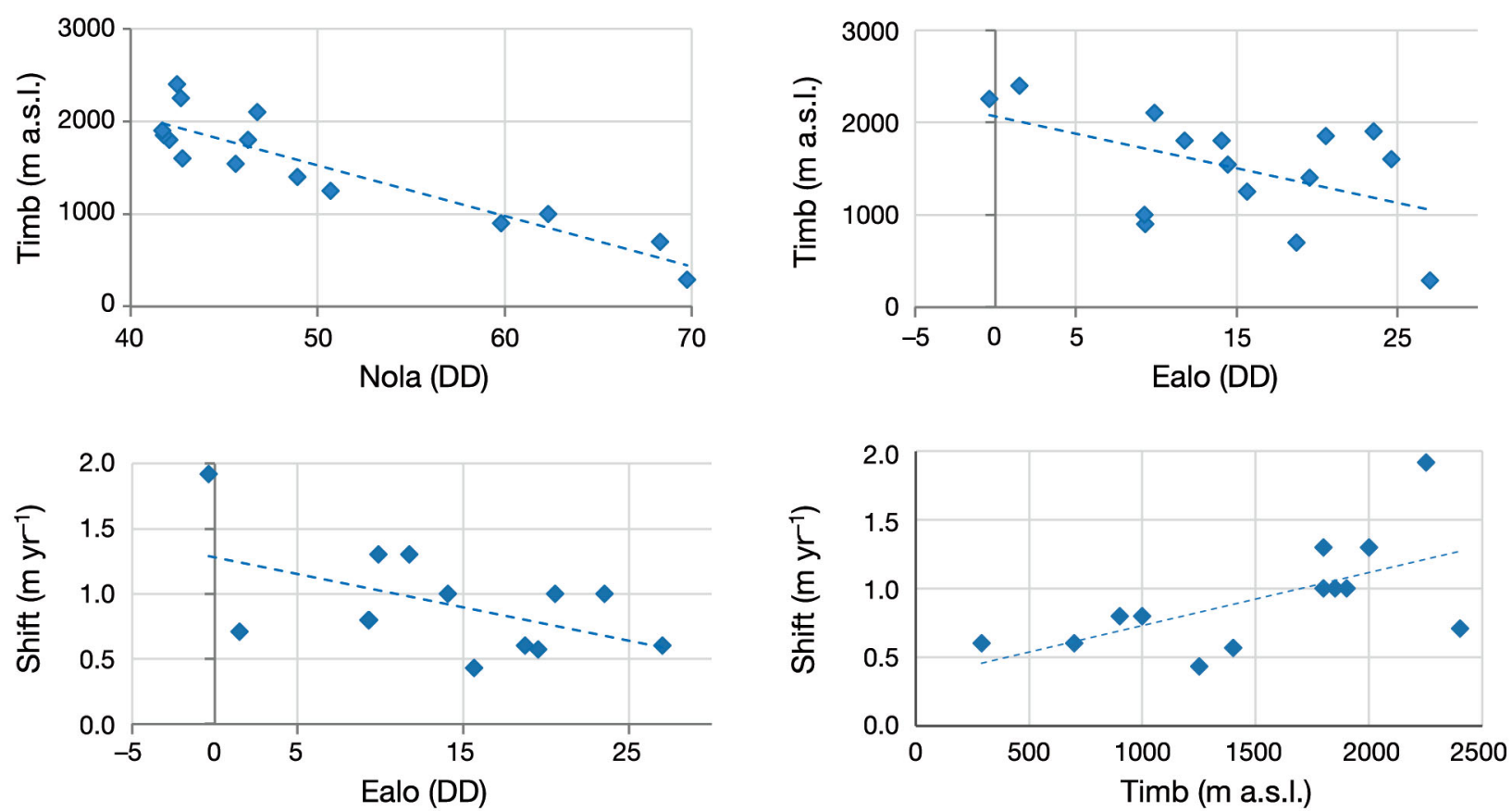

Fig. 5. Univariate graphs of the relationships of dependent variables, viz. timberline (Timb) and treeline shift per year (Shift), and their explanatory variables. Nola: north latitude; Ealo: east longitude; DD: decimal degrees

al. 2009), only a few published studies have included quantitative data about treeline shifts (Devi et al. 2008, Kullman \& Öberg 2009, Diaz-Varela et al. 2010, Van Bogaert et al. 2011). Additionally, our knowledge of the spatial patterns in treeline ecotone shifts at the landscape scale is still surprisingly poor, except for some studies from subarctic areas, the Ural Mountains and the Alps (Lloyd et al. 2002, DiazVarela et al. 2010, Hagedorn et al. 2014). In the 15 studied mountain units, the values of treeline shift ranged from 0.43 to $1.9 \mathrm{~m} \mathrm{yr}^{-1}$, showing a rather distinct spatial pattern of the dynamics within European mountains. The observed treeline shift had a significant positive relationship only with northern latitude and a weak positive relationship with mountainrange size (i.e. the size of the whole mountain massif; Fig. 3). Nevertheless, this illustrates the importance of the mass elevation effect (Körner 2012), and partially explains why treelines could be at different altitudes at the same latitude. Small negative regressions with east longitude and timberline elevation are shown in Fig. 5. There was no apparent dependence of the treeline shift rate on climatic parameter changes between the periods 1961-1990 and 1991-2015.

A whole forest vegetation zone shift is a complex process, as not only the life strategies of an individual tree need to be considered, but plant, animal and microorganism species and their interrelationships, as well as the relationships to their specific microhab- itats (including soil conditions), are also involved (Urban et al. 2012). Across all regions, we identified several important obstacles to treeline shifts, often related to site properties, such as significant rockiness, having shallow or low-nutrient soils, extreme relief causing disturbances by avalanches, snow gliding or wind damage (data from the Pyrenees, Apennines, Shara, Northern Dinaric, Low Tatra and Giant Mountains; see Fig. 2). Soil heterogeneity certainly has an important role in plant responses to climate change, and could also maintain the resilience of the community assemblages (Fridley et al. 2011). Another group of obstacles includes extreme climatic parameters, especially in winter (reported e.g. from the Pyrenees, Apennines, Pirin, Central Balkan, Northern Dinaric and Giant Mountains; Fig. 2). Their combination can result in edaphic and/or climatic unsuitability of habitats where species could potentially migrate. Climatically and edaphically suitable sites will likely decline over the next century, particularly in mountain landscapes (Bell et al. 2014). Therefore, trees in the treeline ecotone will colonize previously forested habitats. The colonization success of individual forest communities is affected by differences in species dispersal and recruitment behaviour (Dullinger et al. 2004, Jonášová et al. 2010). For these reasons, colonization of new forest habitats by the next tree generation may not be successful and may result in loss of species diversity (Honnay et al. 2002, Ibáñez et al. 2009, Dobrowski et 
al. 2015), as reported from Macedonia, Slovenia, the Czech Republic, Slovakia and Norway (Fig. 4).

Another limiting factor is the existence of strong adaptation mechanisms of the dominant tree species which allow them to survive in their current distribution areas. Species migration is likely to be slow due to the limited quantity of climatically and edaphically suitable sites and the slow velocity of seed dispersal and tree regeneration, and will be hampered even more by fragmentation of high mountain landscapes caused by human activities, including brush invasion in abandoned meadows (Gartzia et al. 2014). A vertical shift in a vegetation zone involves not only single species of plants, animals and microorganisms, but also their interrelationships and links to soil conditions. The speed at which climatic conditions change will be different from changes in the soil conditions due to the slowness of soil-forming processes. Soil types and conditions (cambisol versus podzol) are crucial obstacles for the shift from a beech forest zone into the spruce forest zone in the Czech Republic (Vacek \& Mat jka 2010). According to other sources, the dominant tree species can influence soil formation processes (especially humus forms). Under favourable climatic and orographic conditions, beech is able to change its soil conditions over decades to centuries (J. Macku unpubl. data).

Significant changes in biodiversity must be expected in all of the mountain areas of interest. We found that biodiversity declined particularly in the southern regions of Europe, where the timberline is situated at higher elevations and human impact is mostly longer-lasting (Fig. 4). Similarly, Pauli et al. (2012) reported an increase in species richness of mountain grasslands across Europe except for Mediterranean regions, and assigned this different response of the southern regions to decreased water availability. On the other hand, ecosystems which exhibited biodiversity increases were not only enriched by migrant species, but the assemblages underwent thermophilization, i.e. cold-adapted species declined and more warm-adapted species spread (Gottfried et al. 2012). However, not all species are able to track climate changes. It is expected that around $40 \%$ of habitats will become climatically unsuitable for many mountain species, particularly endemic ones, increasing their extinction probability during this century (Dullinger et al. 2012). The abandonment of traditional land use forms is another source of this loss, which may be a more important driver than temperature increase (Fig. 4). Serious biodiversity losses in mountain meadows were reported from Spain, Italy, Macedonia, Bulgaria, Slovenia and Slovakia. There- fore, controlled grazing must occur in order to maintain alpine grasslands (Dirnböck et al. 2003). Unfortunately, grazing is still active only in smaller parts of European mountains (e.g. in the Central Alps and the Central Balkan Mountains, but pasturing can also negatively affect vegetation diversity) and sometimes does not serve to maintain alpine grassland. The same is true for grassland management, which can help to maintain mountain species and decrease habitat loss. A serious biodiversity loss in mountain meadows was reported from the Pyrenees, the Apennines, and the Shara, Pirin, Central Balkan, Northern Dinaric and Low Tatra Mountains (Fig. 4).

In forests, species responses to climate change may be equivocal; some recent studies indicated contradictory shifts in species distributions (e.g. Lenoir et al. 2008, Zhu et al. 2012, Rabasa et al. 2013). This disparity is widely discussed and assigned to the great variety of non-climatic factors or even tree ontogeny (Grytnes et al. 2014, Lenoir \& Svenning 2015, Máliš et al. 2016). Disturbances leading to tree mortality may also play an important role (Cudlín et al. 2013); changes in tree canopy cover modify light availability and microclimate and can induce the thermophilization of forest vegetation (De Frenne et al. 2015, Stevens et al. 2015). The loss of this microclimate buffering effect of forests may induce a biotic homogenization of forests (Savage \& Vellend 2015) or the creation of novel non-analogical communities, such as oak-pine forests (Urban et al. 2012), which may be a new threat to forest biodiversity.

The observed changes in treeline forest ecosystems are often related to changes in land-use intensity (Theurillat \& Guisan 2001, Alados et al. 2014). According to climate change predictions and the recent and future exploitation intensity of European mountains, trees and forest communities will shift upward due to land use change or climate change or both. Reduced land-use intensity certainly will interact with climate change by facilitating or inhibiting species occurrence, and will accelerate forest expansion above the present treeline, particularly to previously forested habitats (Theurillat \& Guisan 2001). The simultaneous action of both main treeline shift drivers, viz. temperature increase and decrease in land use intensity, was recorded from all of our studied mountain areas. The extensive differences in timberline and treeline elevations in almost all studied mountains (Table 1) indicate the anthropo-zoogenic treeline type (according to Ellenberg 1998). In most mountains (e.g. in the Apennines, Shara Mountains, Central Balkans and Alps), land use is the prevailing factor influencing vegetation drift (Fig. 5). Previous 
research showed that the upward shift of the treeline in the Swiss Alps was predominantly attributable to land abandonment, and only in some situations to climate change (Gehrig-Fasel et al. 2007). In the Apennines in the last few decades, tree establishment has been mainly controlled by land use, while tree growth has been controlled by climate, pointing to a minor role played by climate in shaping the current treeline (Palombo et al. 2013).

The impact of climate change and the connected land use change on biodiversity and ecosystem services provision in several European countries is summarized by Wielgolaski et al. (2017), and Kyriazopoulos et al. (2017) (both this Special), and Sarkki et al. (2016). One of the possible adaptive management options in response to climate change, assisted migration as human-assisted movement of species, has been frequently debated in the last few years (SteMarie et al. 2011). It is possible to apply it as a type of assisted colonization, i.e. intentional movement and release of an organism outside its indigenous range to avoid extinction of populations of the focal species (e.g. Macedonian pine species), or as an ecological replacement, i.e. the intentional movement and release of an organism outside its indigenous range to perform a specific ecological function (e.g. planting of Pinus mugo in the Alps; IUCN/SSC 2013).

\section{CONCLUSIONS}

The analysis of 11 mountain areas across Europe showed that with increasing latitude, the treeline and altitudinal width of the treeline ecotone significantly decreases, as do the significance of climatic and soil parameters as barriers against tree species shift. Although temperature is the overwhelming controlling factor of tree growth and establishment in temperate and boreal treeline ecotones, late-seasonal drought might also play a driving role in Mediterranean treeline ecotones. Longitude was less influential, mostly affecting climate and land use change effects on increased biodiversity loss, as well as the size of the area that forms one mesoclimate unit affecting altitudinal ecotone width. The biggest part of the commonly observed remaining variability in mountain vegetation near the treeline in Europe seems to be caused by geomorphological, geological, pedological and microclimatic variability in combination with different land use history and the present socio-economic relations. The observed differences in climatic parameters between the mountain areas of interest in comparison with the reference period $1960-1990\left(0.9^{\circ} \mathrm{C}\right)$ have not explained the relatively high differences in the rate of treeline shift per year $(1.49 \mathrm{~m})$. The predicted variability in temperature increase due to global warming $\left(1.2-2.6^{\circ} \mathrm{C}\right.$ in 2050 and $2.2-5.3^{\circ} \mathrm{C}$ in 2100 ) could lead to a much bigger differentiation in treeline ecotone biodiversity and ecosystem processes between southern and northern European mountains in the future. Therefore, these differences must be taken into account by scientists and EU policy makers when formulating efficient adaptive forest management strategies for treeline ecosystems at the European level (e.g. assisted migration of adapted genotypes).

Acknowledgements. This paper is based firstly upon work from the COST Action ES 1203 SENSFOR, supported by COST (European Cooperation in Science and Technology; www.cost.eu). This international work was further supported by projects granted by the Ministry of Education Youth and Sports of the Czech Republic, grant NPU I LO1415 and LD 14039, by the agency APVV SR under projects APVV-14-0086 and APVV-15-0270. We acknowledge the E-OBS dataset from the EU-FP6 project ENSEMBLES (http://ensembles-eu.metoffice.com) and the data providers in the ECA\&D project (www.ecad.eu)

\section{LITERATURE CITED}

Alados CL, Errea P, Gartzia M, Saiz H, Escós J (2014) Positive and negative feedbacks and free-scale pattern distribution in rural-population dynamics. PLOS ONE 9: e114561

Allen CD, Macalady AK, Chenchouni H, Bachelet D and others (2010) A global overview of drought and heatinduced tree mortality reveals emerging climate change risks for forests. For Ecol Manag 259:660-684

Amidžić L, Bartula M, Jarić S (2012) Syntaxonomy overview of vegetation of Šar Planina in the Balkan Peninsula. Vegetos 25:348-360

* Aune S, Hofgaard A, Söderström L (2011) Contrasting climate and land use driven tree encroachment pattern of sub-arctic tundra in Northern Norway and Kola Peninsula. Can J For Res 41:437-449

Barbeito I, Dawes M, Rixen C, Senn J, Bebi P (2012) Factors driving mortality and growth at treeline: a 30 -year experiment of 92000 conifers. Ecology 93:389-401

Batllori E, Camarero JJ, Ninot JM, Gutiérrez E (2009) Seedling recruitment, survival and facilitation in alpine Pinus uncinata treeline ecotones. Implications and potential responses to climate warming. Glob Ecol Biogeogr 18:460-472

Bebi P, Teich M, Hagedorn F, Zurbriggen N, Brunner SH, Grét-Regamey A (2012) Veränderung von Wald und Waldleistungen in der Landschaft Davos im Zuge des Klimawandels. Schweiz Z Forstwes 163:493-501

Bell DM, Bradford JB, Lauenroth WK (2014) Mountain landscapes offer few opportunities for high elevation tree species migration. Glob Change Biol 20:1441-1451

Bergant K (2006) Climate change scenarios for Macedonia. University of Nova Gorica, Center for Atmospheric 
Research, Nova Gorica

Bodin J, Badeau V, Bruno E, Cluzeau C, Moisselin JM, Walther GR, Dupouey JL (2013) Shifts of forest species along an elevational gradient in Southeast France: climate change or stand maturation? J Veg Sci 24:269-283

Boncina A (2011) History, current status and future prospects of uneven-aged forest management in the Dinaric region: an overview. Forestry 84:467-478

Breshears DD, Cobb NS, Rich PM, Price KP and others (2005) Regional vegetation die-off in response to globalchange-type drought. Proc Natl Acad Sci USA 102: 15144-15148

Camarero JJ, García-Ruiz JM, Sangüesa-Barreda G, Galván JD and others (2015a) Recent and intense dynamics in a formerly static Pyrenean treeline. Arct Antarct Alp Res 47:773-783

* Camarero JJ, Gazol A, Galván JD, Sangüesa-Barreda G, Gutiérrez E (2015b) Disparate effects of global-change drivers on mountain conifer forests: warming-induced growth enhancement in young trees vs. $\mathrm{CO}_{2}$ fertilization in old trees from wet sites. Glob Change Biol 21:738-749

Chen IC, Hill JK, Ohlemüller R, Roy DB, Thomas CD (2011) Rapid range shifts of species associated with high levels of climate warming. Science 333:1024-1026

Cudlín P, Seják J, Pokorný J, Albrechtová J, Bastian O, Marek M (2013) Forest ecosystem services under climate change and air pollution. In: Matyssek R, Clarke N, Cudlín P, Mikkelsen TN, Tuovinen JP, Wiesner G, Paoletti E (eds) Climate change, air pollution and global challenges: understanding and perspectives from forest research. Developments in Environmental Science Vol 13. Elsevier, Oxford, p 521-546

Dalen L, Hofgaard A (2005) Differential regional treeline dynamics in the Scandes mountains. Arct Antarct Alp Res 37:284-296

WDawes MA, Philipson CD, Fonti P, Bebi P, Hättenschwiler S, Hagedorn F, Rixen C (2015) Soil warming and $\mathrm{CO}_{2}$ enrichment induce biomass shifts in alpine tree line vegetation 2014. Glob Change Biol 21:2005-2021

* De Frenne P, Rodríguez-Sánchez F, De Schrijver A, Coomes DA, Hermy M, Vangansbeke P, Verheyen K (2015) Light accelerates plant responses to warming. Nat Plants 1: 15110

Devi N, Hagedorn F, Moiseev P, Bugmann H, Shiyatov SG, Mazepa V, Rigling A (2008) Expanding forests and changing growth forms of Siberian larch at the treeline of the Polar Urals during the 20th century. Glob Change Biol 14:1581-1591

Diaz-Varela R, Colombo R, Meroni M, Calvo-Iglesias MS, Buffoni A, Tagliaferri A (2010) Spatio-temporal analysis of alpine ecotones. A spatial explicit model targeting altitudinal vegetation shifts. Ecol Model 221:621-633

Dirnböck T, Dullinger S, Grabherr G (2003) A regional impact assessment of climate and land-use change on alpine vegetation. J Biogeogr 30:401-417

Dobrowski SZ, Swanson AK, Abatzoglou JT, Holden ZA, Safford HD, Schwartz MK, Gavin DG (2015) Forest structure and species traits mediate projected recruitment declines in western US tree species. Glob Ecol Biogeogr 24:917-927

Dullinger S, Dirnböck S, Grabherr G (2004) Modelling climate change-driven treeline shifts: relative effects of temperature increase, dispersal and invisibility. J Ecol 92:241-252

* Dullinger S, Gattringer A, Thuiller W, Moser D and others
(2012) Extinction debt of high-mountain plants under twenty-first-century climate change. Nat Clim Chang 2: $619-622$

*Elkin C, Gutierrez AG, Leuzinger S, Manusch C, Temperli C, Rasche L, Bugmann $\mathrm{H}$ (2013) A $2^{\circ} \mathrm{C}$ warmer world is not safe for ecosystem services in the European Alps. Glob Change Biol 19:1827-1840

Ellenberg H (1988) Vegetation ecology of Central Europe, 4th edn. Cambridge University Press, Edinburgh

Em H (1986) Spruce southern distribution range. Spruce forest on Shara Mountain in Macedonia. Contrib Macedonian Acad Sci Arts Skopje 5:11-28

F Fajardo A, Piper FI, Pfund L, Körner CH, Hoch G (2012) Variation of mobile carbon reserves in trees at the alpine treeline ecotone is under environmental control. New Phytol 195:794-802

Fridley JD, Grime JP, Askew AP, Moser B, Stevens CJ (2011) Soil heterogeneity buffers community response to climate change in species-rich grassland. Glob Change Biol 17:2002-2011

Gartzia M, Alados CL, Pérez-Cabello F (2014) Assessment of the effects of biophysical and anthropogenic factors on woody plant encroachment in dense and sparse mountain grasslands based on remote sensing data. Prog Phys Geogr 38:201-217

Gehrig-Fasel J, Guisan A, Zimmermann NE (2007) Tree line shifts in the Swiss Alps: climate change or land abandonment? J Veg Sci 18:571-582

Gikov A, Dimitrov P, Zhiyanski M (2016) Land cover dynamics on the northern slope of the Troyan Passage during 30 years period. Probl Geogr 1-2:78-92

* Gonzalez P, Neilson RP, Lenihan JM, Drapek RJ (2010) Global patterns in the vulnerability of ecosystems to vegetation shifts due to climate change. Glob Ecol Biogeogr 19:755-768

Gottfried M, Pauli H, Futschik A, Akhalkatsi M and others (2012) Continent-wide response of mountain vegetation to climate change. Nat Clim Chang 2:111-115

* Grace J, Berninger F, Nagy L (2002) Impacts of climate change on the tree line. Ann Bot 90:537-544

Grunewald K, Scheithauer J (2011) Landscape development and climate change in Southwest Bulgaria (Pirin Mts.). Springer, Heidelberg

Grytnes JA, Kapfer J, Jurasinski G, Birks HH and others (2014) Identifying the driving factors behind observed elevational range shifts on European mountains. Glob Ecol Biogeogr 23:876-884

Hagedorn F, Shiyatov FG, Mazepa VS, Devi NM and others (2014) Treeline advances along the Urals mountain range-driven by improved winter conditions? Glob Change Biol 20:3530-3543

*Hansen AJ, Neilson RP, Dale VH, Flather $\mathrm{CH}$ and others (2001) Global change in forests: responses of species, communities, and biomes. BioScience 51:765-779

*Harsch MA, Bader MY (2011) Treeline form-a potential key to understanding treeline dynamics. Glob Ecol Biogeogr 20:582-596

* Harsch MA, Hulme PE, McGlone MS, Duncan RP (2009) Are treelines advancing? A global meta-analysis of treeline response to climate warning. Ecol Lett 12:1040-1049

*Haylock MR, Hofstra N, Klein Tank AMG, Klok EJ, Jones PD, New M (2008) A European daily high-resolution gridded dataset of surface temperature and precipitation. J Geophys Res Atmos 113:D20119

Hlásny T, Barcza Z, Fabrika M, Balázs B and others (2011) 
Climate change impacts on growth and carbon balance of forests in Central Europe. Clim Res 47:219-236

Hlásny T, Trombik J, Dobor L, Barcza Z, Barka I (2016) Future climate of the Carpathians: climate change hotspots and implications for ecosystems. Reg Environ Change 16:1495-1506

Hofgaard A, Dalen L, Hytteborn H (2009) Tree recruitment above the treeline and potential for climate driven treeline change. J Veg Sci 20:1133-1144

Holtmeier FK (2009) Mountain timberlines. Ecology, patchiness, and dynamics, 2nd edn. Advances in Global Change Research 36. Springer Science \& ScienceMedia B.V., Dordrecht

Holtmeier FK, Broll G (2005) Sensitivity and response of northern hemisphere altitudinal and polar treelines to environmental change at landscape and local scales. Glob Ecol Biogeogr 14:395-410

Honnay O, Verheyen K, Butaye J, Jacquemyn H, Bossuyt B, Hermy M (2002) Possible effects of habitat fragmentation and climate change on the range of forest plant species. Ecol Lett 5:525-530

Huber R, Rigling A, Bebi P, Brand F and others (2013) Sustainable land use in mountain regions under global change: synthesis across scales and disciplines. Ecol Soc 18:36

Ibáñez I, Clark JS, Dietze MC (2009) Estimating colonization potential of migrant tree species. Glob Change Biol 15: 1173-1188

IUCN/SSC (International Union for Conservation of Nature/ Species Survival Commission) (2013) Guidelines for reintroductions and other conservation translocations. Version 1.0. IUCN/Species Survival Commission, Gland

Jankovský L, Cudlín P, Čermák P, Moravec I (2004) The prediction of development of secondary Norway spruce stands under the impact of climatic change in the Drahany highlands (The Czech Republic). Ekologia (Bratisl) 23(Suppl 2):101-112

Jeník J, Lokvenc T (1962) Die alpine Waldgrenze im Krkonoše Gebirge. Rozpravy SAV. Řada matematických a prrírodních věd 72. Československá akademie věd, Praha

Jobbágy EG, Jackson RB (2000) Global controls of forest line elevation in the northern and southern hemispheres. Glob Ecol Biogeogr 9:253-268

Jonášová M, Vávrová E, Cudlín P (2010) Western Carpathian mountain spruce forest after a windthrow: natural regeneration in cleared and uncleared areas. For Ecol Manag 259:1127-1134

Kittel TGF, Steffen WL, Chapin FS (2000) Global and regional modelling of Arctic-boreal vegetation distribution and its sensitivity to altered forcing. Glob Change Biol 6:1-18

Klopcic M, Jerina K, Bončina A (2010) Long-term changes of structure and tree species composition in Dinaric uneven-aged forests: Are red deer an important factor? Eur J For Res 129:277-288

Klopcic M, Simončič T, Bončina A (2015) Comparison of regeneration and recruitment of shade-tolerant and lightdemanding tree species in mixed uneven-aged forests: experiences from the Dinaric region. Forestry 88:552-563

Körner C (2003) Alpine plant life: functional plant ecology of high mountain ecosystems; with 47 tables. Springer Science \& Business Media B.V., Dordrecht

Körner C (2012) Alpine treelines. Functional ecology of the global high elevation tree limits. Springer, Basel

Körner C, Paulsen J (2004) A world-wide study of high alti- tude treeline temperatures. J Biogeogr 31:713-732

KKulakowski D, Bebi P, Rixen C (2011) The interacting effects of land use change, climate change and suppression of natural disturbances on landscape forest structure in the Swiss Alps. Oikos 120:216-225

Kullman L (1988) Holocene history of the forest-alpine tundra ecotone in the Scandes Mountains (central Sweden). New Phytol 108:101-110

Kullman L (1999) Early holocene tree growth at a high elevation site in the northernmost Scandes of Sweden (Lapland): a palaeobiogeographical case study based on megafossil evidence. Geogr Ann 81:63-74

Kullman L (2007) Tree line population monitoring of Pinus sylvestris in the Swedish Scandes, 1973-2005: implications for tree line theory and climate change ecology. J Ecol 95:41-52

* Kullman L, Öberg L (2009) Post-Little Ice Age treeline rise and climate warming in the Swedish Scandes: a landscape ecological perspective. J Ecol 97:415-429

Kyriazopoulos AP, Skre O, Sarkki S, Wielgolaski FE, Abraham EM, Ficko A (2017) Human-environment dynamics in European treeline ecosystems: a synthesis based on the DPSIR framework. Clim Res 73:17-29

Lenoir J, Svenning JC (2015) Climate-related range shifts a global multidimensional synthesis and new research directions. Ecography 38:15-38

Lenoir J, Gégout JC, Marquet PA, de Ruffray P, Brisse H (2008) A significant upward shift in plant species optimum elevation during the 20th century. Science 320: 1768-1771

Lindner M, Fitzgerald JB, Zimmermann NE, Reyer C and others (2014) Climate change and European forests: What do we know, what are the uncertainties, and what are the implications for forest management? J Environ Manag 146:69-83

พ Lloyd AH, Rupp TS, Fastie CL, Srafield AM (2002) Patterns and dynamic of treeline advance on the Seward Penisula, Alaska. J Geophys Res 107:8161

* Máliš F, Kopecký M, Petř́́k P, Vladovič J, Merganič J, Vida $\mathrm{T}$ (2016) Life-stage, not climate change, explains observed tree range shifts. Glob Change Biol 22:1904-1914

Mathisen IE, Mikheeva A, Tutubalina OV, Aune S and Hofgaard A (2014) Fifty years of tree line change in the Khibiny Mountains, Russia: advantages of combined remote sensing and dendroecological approaches. Appl Veg Sci 17: 6-16

* Millar CI, Stephenson NL (2015) Temperate forest health in an era of emerging megadisturbance. Science 349: 823-826

Mina M, Bugmann H, Klopcic M, Cailleret M (2017) Accurate modeling of harvesting is key for projecting future forest dynamics: a case study in the Slovenian mountains. Reg Environ Change 17:49-64

Moen J, Aune K, Edenius L, Angerbjörn A (2004) Potential effects of climate change on treeline position in the Swedish mountains. Ecol Soc 9:16, www.ecologyand society.org/vol9/iss1/art16

*Palombo C, Chirici G, Marchetti M, Tognetti R (2013) Is land abandonment affecting forest dynamics at high elevation in Mediterranean mountains more than climate change? Plant Biosyst 147:1-11

* Palombo C, Marchetti M, Tognetti R (2014) Mountain vegetation at risk: current perspectives and research reeds. Plant Biosyst 148:35-41

Pauli H, Gottfried M, Dullinger S, Abdaladze O, Akhalkatsi 
M, Alonso JLB, Grabherr G (2012) Recent plant diversity changes on Europe's mountain summits. Science 336: 353-355

* Payette S, Fortin MJ, Gamachet I (2001) The subarctic forest-tundra: the structure of a biome in a changing climate. BioScience 51:709-718

Pearson GR, Dawson TP (2003) Predicting the impacts of climate change on the distribution of species: Are bioclimate envelope models useful? Glob Ecol Biogeogr 12: 361-371

Pedrotti F (2013) Plant and vegetation mapping. Geobotany Studies. Springer-Verlag, Berlin

*Peñuelas J, Boada M (2003) A global change-induced biome shift in the Montseny mountains (NE Spain). Glob Change Biol 9:131-140

Piovesan G, Biondi F, Filippo AD, Alessandrini A, Maugeri M (2008) Drought driven growth reduction in old beech (Fagus sylvatica L.) forests of the central Apennines, Italy. Glob Change Biol 14:1265-1281

Rabasa SG, Granda E, Benavides R, Kunstler G and others (2013) Disparity in elevational shifts of European trees in response to recent climate warming. Glob Change Biol 19:2490-2499

Raev I, Zhelev P, Grozeva M, Markov I and others (2011) Programme of measures for adaptation of forests in Bulgaria and mitigate the negative impact of climate change on them. Project FUTURE forest helping Europe tackle climate change. INTERREG IVC, ERDF, Sofia

Sarkki S, Ficko A, Grunewald K, Nijnik M (2016) Benefits from and threats to European treeline ecosystem services: an exploratory study of stakeholders and governance. Reg Environ Change 16:2019-2032

Savage J, Vellend M (2015) Elevational shifts, biotic homogenization and time lags in vegetation change during 40 years of climate warming. Ecography 38:546-555

Schwörer C, Henne PD, Tinner W (2014) A model-data comparison of Holocene timberline changes in the Swiss Alps reveals past and future drivers of mountain forest dynamics. Glob Change Biol 20:1512-1526

Šmilauer P, Lepš J (2014) Multivariate analysis of ecological data using Canoco 5. Cambridge University Press, Cambridge

Ste-Marie C, Nelson EA, Dabros A, Bonneau ME (2011) Assisted migration: introduction to a multifaceted concept. For Chron 87:724-730

Stevens JT, Stafford HD, Harrison S, Latimer AM (2015) Forest disturbance accelerates thermophilization of understory plant communities. J Ecol 103:1253-1263

Strid A, Andonoski A, Andonovski V (2003) Alpine biodiversity in Europe. Ecological Studies 167. Springer-Verlag, Berlin

Tattoni C, Ciolli M, Ferretti F, Cantiani MG (2010) Monitoring spatial and temporal pattern of Paneveggio forest (Northern Italy) from 1859 to 2006. iForest Biogeosci For 3:72-80

Ter Braak CJF, Šmilauer P (2012) Canoco reference manual and user's guide: software for ordination (version 5.0). Microcomputer Power, Ithaca, NY

Theurillat JP, Guisan A (2001) Potential impact of climate change on vegetation in the European Alps: a review. Clim Change 50:77-109

Tømmervik H, Wielgolaski FE, Neuvonen S, Solberg B, Høgda KA (2005) Biomass and production on a landscape level in the mountain birch forests. In: Wielgolaski FE (ed) Plant ecology, herbivory and human impact in
Nordic mountain birch forests. Ecos Studies 180. Springer, Berlin, p 53-70

Treml V, Banaš M (2000) Alpine timberline in the High Sudetes. Acta Univ Carol Geogr 15:83-99

Treml V, Chuman T (2015) Ecotonal dynamics of the altitudinal forest limit are affected by terrain and vegetation structure variables: an example from the Sudetes Mountains in Central Europe. Arct Antarct Alp Res 47:133-146

* Treml V, Migo P (2015) controlling factors limiting timberline position and shifts in the Sudetes: a review. Geogr Pol 88:55-70

U Urban MC, Tewksbury JJ, Sheldon KS (2012) On a collision course: competition and dispersal differences create noanalogue communities and cause extinctions during climate change. Proc R Soc Lond B Biol Sci 279:2072-2080

Vacek S, Matějka K (2010) State and development of phytocenoses on research plots in the Krkonoše Mts. forest stands. J For Sci 56:505-517

Van Bogaert R, Haneca K, Hoogesteger J, Jonasson C, de Dapper M, Callaghan TV (2011) A century of tree line changes in sub-Arctic Sweden shows local and regional variability and only a minor influence of 20th century climate warming. J Biogeogr 38:907-921

Van Gils H, Batsukh O, Rossiter D, Munthali W, Liberatoscioli E (2008) Forecasting the pattern and pace of Fagus forest expansion in Majella National Park, Italy. Appl Veg Sci 11:539-546

Velchev V (1997) Types of vegetation. In: Yordanova M, Donchev D (eds) Geography of Bulgaria. BAN, Sofia, p 269-283 (in Bulgarian)

Vladovič J, Merganič J, Máliš F, Križová E and others (2014) The response of forest vegetation diversity to changes in edaphic-climatic conditions in Slovakia. Technická univerzita vo Zvolene, Zvolene (in Slovak)

* Vrška T, Adam D, Hort L, Kolář T, Janík F (2009) European beech (Fagus sylvatica L.) and silver fir (Abies alba Mill.) rotation in the Carpathians - a developmental cycle or a linear trend induced by man? For Ecol Manag 258: 347-356

Wielgolaski FE (ed) (2005) Plant ecology, herbivory, and human impact in Nordic mountain birch forests. Ecological Studies 180. Springer Verlag, Berlin

Wielgolaski FE, Hofgaard A, Holtmeier FK (2017) Sensitivity to environmental change of the treeline ecotone and its associated biodiversity in European mountains. Clim Res 73:151-166

Wieser G, Tausz M (2007) Trees at their upper limit. Treelife limitation at the alpine timberline. Springer, Dordrecht

Wieser G, Holtmeier FK, Smith WK (2014) Treelines in a changing global environment. In: Tausz M, Grulke N (eds) Trees in a changing environment. Plant Ecophys 9. Springer, Dordrecht, p 221-263

Zhiyanski M, Kolev K, Sokolovska M, Hursthouse A (2008) Tree species effect on soils in Central Stara Planina Mountains. Nauka Gorata 4:65-82

Zhiyanski M, Gikov A, Nedkov S, Dimitrov P, Naydenova L (2016) Mapping carbon storage using land cover/land use data in the area of Beklemeto, Central Balkan. In: Koulov B, Zhelezov G (eds) Sustainable mountain regions: challenges and perspectives in southeastern Europe. Springer, Basel, p 53-65

Zhu K, Woodall CW, Clark JS (2012) Failure to migrate: lack of tree range expansion in response to climate change. Glob Change Biol 18:1042-1052 